\title{
Fruitful Inspiration: Fresh View on Bakhtinian Dialogism in Some Fields of the Humanities
}

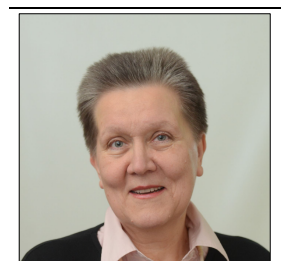

\author{
Vera Kirzhaeva \\ National Research Mordovia State \\ University, Russia
}

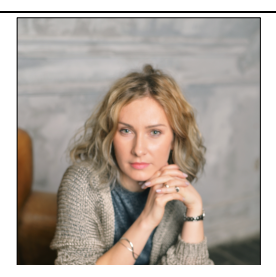

Elizaveta Maslova

Plekhanov Russian University of

Economics, Russia

\section{Abstract}

A review of Matthias Freise (ed.), 2018., Inspired by Bakhtin: Dialogic Methods in the Humanities, Boston: Academic Studies Press, 2018.

This review provides an analysis of a collection of articles that demonstrate the possibilities of applying dialogic methods in various fields of the humanities. The authors of these articles show how Bakhtinian dialogism functions in the history and theory of literature, sociology and design, in the study of Platonic dialogues, the image of the Other in contemporary cinema and in the practice of psychoanalysis.

The reviewers emphasize that the book fits well with the Bakhtin Studies trend. The dialogical approach to the phenomena of human consciousness allows a new research paradigm that differs from the natural sciences. The emphasis should be placed on the internal relations among the objects of the humanities research. The latter should be considered as a form of dialogue and described within the framework of dialogic methods. Each of the authors gives their own answer to the questions formulated by M. Freise: "How can we define a dialogic method of research in the humanities in general, what would be the specific qualities of such a method?" As a result, reviewers believe, a convincing picture of the internal dialogism of the humanities is constructed in the book.

Despite the fact that special articles on the dialogic method in pedagogy are not included in the book, reviewers believe that the book will be useful for theorists and practitioners of education.

Keywords: Bakhtin; Bakhtin Studies; Dialogism; Dialogic Relations; Dialogic Methods in the Humanities.

Vera Kirzhaeva works as a professor of Russian at the Philology department at the Mordovia State University in Saransk. She holds a degree of a Doctor of Pedagogy. Her main research interests are Bakhtin Studies, Russian émigré education in 1920-40s, and Russian intellectual history.

Elizaveta Maslova works as a university lecturer in Moscow. She holds a PhD degree. Her special interests include LCCl exams preparation and development of online courses, Bakhtin and contemporary US novel.

\section{2des}

Mikhail Bakhtin's ideas of dialogue and dialogic imagination have been crucially important for the world of the humanities for many years (Holquist, 2002; Morson, Emerson, 1990; Osovskiy, 1997; Polyuha, Thomson, Wall, 2012; Makhlin, 2015; Osovsky, 2018). The application of Bakhtinian dialogics in the education sphere has also been noteworthy. An application of Bakhtinian dialogics to education can be found in the works of Russian philosopher and educator Vladimir Bibler and his school of the dialogue of 


\section{Fruitful Inspiration: Fresh View on Bakhtinian Dialogism in Some Fields of the Humanities Vera Kirzhaeva, Elizaveta Maslova}

cultures in 1990s (Bibler, 1991) and later in the dialogical pedagogy, theory and practice (Matusov, 2009; Matusov, Marjanovic-Shane, Gradovski, 2019; Brandist, Gardiner, White, Mika, 2020).

Contemporary interpretations of the ideas and legacy of Mikhail Bakhtin strongly call for new approaches. This is exactly the path followed by the authors of the collection "Inspired by Bakhtin. Dialogic Methods in the Humanities." The editor of the book - the famous Slavic scholar and the researcher of Bakhtin's literary and philosophical works, professor at the University of Heidelberg, Matthias Freise determines the position of the authors from the very beginning of the book: "Many scholars around the world are inspired by Mikhail Bakhtin's ideas. For them, his using of the term "dialogue" is one of the key concepts in the humanities" ( $p$. Vl). Simultaneously the book's aim is to answer the following principal questions: "Despite the abundance of interpretations of Bakhtin's teachings, two fundamental questions regarding his 'dialogism' still seem to be unanswered: first - do the objects of other humanities have dialogical qualities similar to those literature has; second - how can we define a dialogic method of research in the humanities in general, what would be the specific qualities of such a method?" (p. VI). The editor also points out to the specific tasks that the researchers set for themselves. Using Bakhtin's terminology, we can say that the voices of each discipline of the humanities merge into a common chorus:

In this volume, seven scholars - from different countries, rooted in different cultures, working in different fields of the humanities - propose answers to the following questions: What in my field of study can be considered a dialogic approach and why is a dialogic approach essential in my field in order to disclose the specific qualities of the material to be analyzed? From these two fundamental questions, the specific questions in the respective fields of study arise: How dialogic is the intercultural encounter in contemporary cinema? What is dialogic design? What are the presuppositions of a successful therapeutic dialogue? On what terms a literary history can be called dialogic? How dialogic is postmodern authorship? How dialogic are Plato's philosophical dialogues? What distinguishes dialogical sociology? (p. VI).

However, it is not clear what Bakhtin's ideas they discuss. We sometimes had an impression the researchers entered into dialogue with fairly general and rather vague categories of Bakhtin's ideas in order to discuss some specific problems.

The choice of dialogism as a framework for Bakhtin's theory seems logical for the editor and the authors. The dialogical relations of a person with the world and with one's own self were already indicated in Bakhtin's first publication - the 1919 essay "Art and Answerability." Developing the thesis about the immanent dialogism of the phenomenon of "answerability," the young philosopher writes: "It is not only mutual answerability that art and life must assume, but also mutual liability to blame. The poet must remember that it is his poetry which bears the guilt for the vulgar prose of life, whereas the man of everyday life ought to know that the fruitlessness of art is due to his willingness to be unexacting and to the unseriousness of the concerns in his life" (Bakhtin, 1990, p. 1-2). Here one can see the first outline of internal dialogism that will reappear in Dostoevsky's Poetics as an imperative: "To be means to communicate dialogically. When dialogue ends, everything ends. Thus dialogue, by its very essence, cannot and must not come to an end" (Bakhtin, 1984, p. 252).

For M. Freise, Bakhtin's understanding of dialogism becomes the basis of that spectrum of dialogic methods, which should become a kind of new methodology for the humanities. From the position of M. Freise, Bakhtin's dialogism arises as a logical outcome of the scholar's work with the main neo-Kantian texts. 


\title{
Fruitful Inspiration: Fresh View on Bakhtinian Dialogism in Some Fields of the Humanities Vera Kirzhaeva, Elizaveta Maslova
}

\begin{abstract}
Dialogicity, thus, is the one common quality of phenomena expressing relationships. Therefore, a dialogical approach should be the universal tool of understanding them. To examine phenomena of relationship is the long sought common quality of the various disciplines within humanities. However, this quality, and with it the very nature of such phenomena, dissolves when we, conditioned by natural sciences, redefine relationships as objects. For this reason, all disciplines in the humanities are called to develop dialogical approaches, which are the most adequate to the phenomena they examine - be it psychic, social, cultural, epistemological or historical (p. XXVII).
\end{abstract}

The relations between the researcher and the object of the study, which are so different in the field of natural sciences and in the field of the humanities, determine the possibility/impossibility of internal dialogism in both scientific disciplines. At the turn of the 1930s and 1940s, returning to reflections on the essence of the knowledge of humanness in his work "To the Philosophical Foundations of the Humanities," Bakhtin emphasized the very difference in the approaches to the object of the study in the natural sciences and in the humanities and the relations that arise from this.

Knowledge of things and knowledge of personality. These must be characterized as limits: the pure dead thing, having only externality, existing only for the other and capable of being completely and finally revealed by the one-sided act of this (knowing) other. Such a thing, lacking its own inalienable and unconsumable core, can only be an object of practical interestedness. The second limit is thought about God in the presence of God, dialogue, questioning, prayer $<\ldots>$ A question is in this case posed by the one knowing not to himself nor to a third in the presence of a dead thing, but to the one known (Hirschkop, 1999, p. 200).

In his article "The Dialogic Method in Literary History" M. Freise clearly shows how Bakhtin's methodology works within the framework of a specific discipline of the humanities. The approach proposed by the author has the necessary versatility and allows one to extend his conclusions to any space of intellectual history - the history of education, philosophy, culture, linguistics, etc.

\footnotetext{
Scholarship in general - and therefore also literary scholarship - aims at the generalizing and classifying of phenomena. Literary history, like historiography in general, seems to be an exception to this aim. In the field of literary history, any attempt to go beyond description seems to be unscholarly. Contemporary theory of history, ever since Hayden White published his groundbreaking works on the narrativity of historiography, seems to advise scholarship to refrain from any attempt to understand the flow of history. Otherwise, we seem to inevitably end up exploiting history for our own ideological purposes. However, the subjective narrativity of historiography is only one side of a complex correlation between the cultural present and the cultural past, which I would like to call, with reference to Mikhail Bakhtin's teachings, a dialogue (p. 25).
}

Such an attitude should ensure the use of a dialogical approach as a tool for an adequate understanding and interpretation of historical phenomena, in this case, in the literary space.

One of the most important questions posed by M. Freise is what ensures the correct reading of a literary work, its meanings and symbols of the past; where does the point of dialogue between cultures at a great historical distance arise and what ensures their continuity? Revisiting the concept of the epoch as the fundamental element of German literature since the mid-1980s, M. Freise sees in it a fruitful combination of time and style that characterizes cultural and artistic production not only in a certain historical interval, but also in the previous and subsequent periods. This creates a complex theoretical construction, whereby the researcher tries to explain the change of the Renaissance to the Baroque, and the Baroque to the era of Classicism, introduces the concept of "transitional" epochs (mannerism, rococo), etc. The theoretical 


\section{Fruitful Inspiration: Fresh View on Bakhtinian Dialogism in Some Fields of the Humanities \\ Vera Kirzhaeva, Elizaveta Maslova}

base is extremely wide and incudes names from G. Welflin and Yu. Tynyanov to H.G. Gadamer and H.R. Jauss et al.

Hidden dialogue with Bakhtin is, in some form or the other, discernible in most of the articles in the collection. For example, Michal Kaczmarczyk following D. Bohm in the article "Towards a Dialogical Sociology" reflects on the reasons for the complexity of the thought process, during which there is a clash between the momentary understanding of what is happening, and the experience rooted in the consciousness. He defines the process of thought formation as a kind of a blind spot, since having formulated a thought, a person, as a rule, is not able to verbalize how he or she arrived at it. Finding the truth in the course of a sociological study is achieved, from the point of view of the author, precisely through the dialogical approach, partially implemented in the sociological classics of M. Weber and E. Durkheim. One cannot disagree that adding Bakhtin dialogism to the theory and practice of sociology should create new tools for analyzing the phenomena of social life. It will not be amiss to recall here the experience of practical sociology of Bakhtin himself - the article "Experience in Studying the Demand of Collective Farmers," which appeared during the Kustanai exile in Soviet Trade journal and was awarded the Communist Academy medal.

From dialogic sociology to dialogic design - this is how one can define the direction of Klaus Krippendorff's article "Discourses in the Design of Cultural Artifacts," whose author, a theorist and practitioner of architectural design, first of all explores the communication strategies used in planning and implementation of design projects, looks at is the proportion of thought, language and speech in the practice of negotiations and meetings, not only face-to-face, but also through technologies (webinars, forums, chats, etc.). The social constraints imposed on the creative process, and the communicative norms of various communities, including professional ones, create their discourses, and only their proper organization can lead to success in projects. The researcher believes this goal can be achieved with the help of Bakhtin's ideas - from dialogue to polyphony and speech genres:

Bakhtin proposed a way of reading texts not as a sequence of well-formed sentences conceptualized by structural linguists, or as a network of propositions about the world on which logical positivists insist, but as the voices behind written texts. For Bakhtin, these voices belong not only to their authors, which is the primary focus of many contemporary literary interpretations, but also to those written of, explicitly quoted, and implicitly invoked, including the imagined readers. What attracted me to his conceptions is that he always grounded his reading of texts in human speech. Words, he insisted, do not exist until they are spoken, and, when printed, bear the signature of their speakers and listeners without whom we rarely speak (p. 78).

Relying not only on M. Bakhtin, but also on L. Wittgenstein, R. Barthes, M. Foucault, the author analyzes the place of various discourses (from political and sociological to linguistic and even medical) in modern society, determines the laws of their development, emphasizes the role of internal dialogical nature of professional discourse in the development of a language that is understandable not only to members of a particular community, but also to outsiders. According to the researcher, taking into account these factors, improves the design discourse and ensures success of design proposals.

Xiaojing Wang examines internal dialogism as a characteristic feature of the image of the Other in an increasingly open Europe. Her article "Voices in Image: A Methodological and Theoretical Approach to the Dialogic Image of the Other with the European Image of China as an Example" is a typical example of combining the post-structuralist interpretations of the Other, primarily in the philosophy and psychoanalysis of J. Lacan, with the Bakhtinian dialogue. The researcher considers the image of China, formed in the European consciousness from the 13th century, as predominantly monologic and rather arbitrary, as clearly 
illustrated in her examples of the alleged "Chinese" in the discourse of the French Enlightenment. The gradual development of the Chinese culture in the twentieth century, the change in attitudes towards the Chinese immigrants to Europe, the transformation of behavioral stereotypes among representatives of Chinese communities naturally led to the formation of a new perception of the Chinese, whereas economic growth and political changes in China since the late 1980s have changed the very principles of cultural and artistic reproduction of the Chinese world. The author supports her thought by a detailed analysis of films created in Denmark, Iceland, Italy, France, etc., where the plot is based on the nuances of communication between the Chinese characters and the representatives of European culture. According to the author, a new interpretation of China in modern European cinema is rooted in the desire to understand the Other, to enter into dialogue with him, thereby destroying previous stereotypical perceptions, eliminating hostility and creating a field of a friendly dialogue that "heralds a deep and profound cultural transformation, which, as it were, has turned a new page in the cultural histories of Europe and China subject" (p. 170).

Kryštof Boháček's article "Between Socrates and the Stranger: How Dialogic Are Plato's Dialogues?" is partly in tune with Bakhtin's understanding of dialogue in the book on Dostoevsky. However, the Czech scholar is much more preoccupied with the current state of research on Platonic dialogues, their typology, and their structural features. The Platonic dialogues enter into dialogue with the present, and the conversation lasting several millennia is actualized in each epoch, including the time of the author himself. "Apology" is a vivid example of Plato's conversation with each new generation. There is no doubt that

Socrates speaks to the reader, whenever someone starts to read the Apology. As soon as someone opens the text of Apology, the trial of Socrates - the legal dispute between European society and philosophy - is launched anew. The whole text of Apology is actually Plato's effort to revoke the unfortunate judicial process which had ended with the unjust judgment, from Plato's view, to send Socrates to death (p. 22).

It should be noted again that the authors' degree of involvement in Bakhtinian ideas and concepts varies significantly. In this sense, Maria Andrianova's article "Internal Dialogism of Russian Postmodern Literature: Polyphony or Schizophrenia?" is typical of modern literary criticism. Polyphony or schizophrenia are metaphors of two paths along which the prose of Russian postmodernism develops from $\mathrm{A}$. Bitov to $\mathrm{V}$. Pelevin. The brevity of the text does not allow us to fully determine how the presence of traditional and nontraditional dialogues in the novels "Pushkin House," "The Sacred Book of the Werewolf" and others demonstrates their internal dialogism in its Bakhtinian understanding, especially given that the reality constructed by a postmodern writer extremely rarely turns a multitude of voices into true polyphony.

Sometimes Bakhtin's rejection of certain trends in the ideology and culture of the 20th century from Marxism to Freudianism does not become an obstacle for the authors. Thus, Bakhtin's well-known criticism of psychoanalysis does not bother Reinhard Plassmann. In his article "Attachment Patterns in the Bi-Personal Field," he analyses various aspects of the dialogue between a psychoanalyst and a patient.

The main disadvantage of the reviewed collection is the lack of works devoted to the dialogic method in the learning process. Perhaps this is due to the fact that the book is based on reports at the XV International Bakhtin Conference (Stockholm, 2014) only. However, the approaches described in this collection seem quite productive and useful for educators who might benefit from new opportunities of using Bakhtin's dialogic method not only in theory but also in class. This book, whose authors found inspiration in Bakhtin, can itself serve as a source of Bakhtinian inspiration for teachers. Thus, the authors of the review would like to identify those problem areas where, in their opinion, certain elements of Bakhtin's pedagogy should be clarified. Especially promising here are the application of various forms of dialogic education for the junior and middle school; the identification of the national characteristics of educational dialogue, its 
relationship with the social and cultural characteristics of a particular region or country. The dialogical potential of early Bakhtin's texts also needs special consideration in the context of the European philosophical and pedagogical theory of the 1900-1930s. The discussion of the possibilities of Bakhtinian dialogics in the context of new media technologies and their educational potential is to be analyzed in the interdisciplinary way.

\section{References}

Bakhtin, M. M. (1990). Art and answerability: early philosophical essays (M. Holquist \& V. Liapunov, Trans.). Austin: University of Texas Press.

Bakhtin, M. M. (1984). Problems of Dostoevsky's poetics. Minneapolis: University of Minnesota Press.

Bibler, V. S. (1991). Михаил Михайлович Бахтин, или Поэтика культуры (Mikhail Mikhailovich Bakhtin, or the poetics of culture). Moscow: Progress, Gnosis.

Brandist, C., Gardiner, M. E., White, E. Jayne, \& Mika, C. (Eds.). (2020). Bakhtin in the Fullness of Time: Bakhtinian Theory and the Process of Social Education. London: Routledge.

Holquist, M. (2002). Dialogism: Bakhtin and His World. 2nd Edition. L., N.Y.: Routledge.

Freise, M. (Ed.). (2018). Inspired by Bakhtin. Dialogic Methods in the Humanities. Boston: Academic Studies Press.

Makhlin, V. L. (2015). Большое время: Подступы к мышлению М. М. Бахтина (Big time: Approaches to M.M. Bakhtin's thinking). Siedlce: Uniwersytet Przyrodniczo-humanistyczny w Siedlicach.

Matusov, E., Marjanovic-Shane, A., \& Gradovski, M. (2019). Dialogic pedagogy and polyphonic research art: Bakhtin by and for educators, doi: 10.1057/978-1-137-58057-3. New York: Palgrave Macmillan.

Matusov, E. (2009). Journey into Dialogic Pedagogy. Hauppauge, NY: Nova Science Publishers.

Morson, G. S., \& Emerson, C. (1990). Mikhail Bakhtin: Creation of a prosaics. Stanford, CA: Stanford University Press.

Osovskiy, O. Е. (1997). Диалог в большом времени: литературоведческая концепция М. М. Бахтина (Dialogue in the big time: the literary concept of M. M. Bakhtin). Saransk: MGPI.

Osovsky, O. (2018). The destinies of meta-criticism in the era of mega-crisis, Social Sciences. 49 (2), pp. $132-143$.

Polyuha, M., Thomson, C., \& Wall, A. (Eds.). (2012). Dialogues with Bakhtinian Theory: Proceedings of the Thirteenth Mikhail Bakhtin International Conference. London, Ontario: Mestengo Press.

\section{(cc) EY}

New articles in this journal are licensed under a Creative Commons Attribution 4.0 United States License.

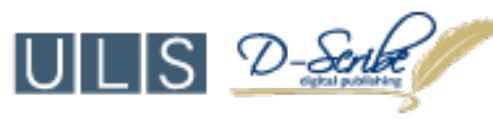

This journal is published by the University Library System, University of Pittsburgh as part of its D-Scribe Digital Publishing Program and is cosponsored by the University of Pittsburgh Press. 